\title{
RAD51D Gene
}

National Cancer Institute

\section{Source}

National Cancer Institute. RAD51D Gene. NCI Thesaurus. Code C116930.

This gene plays a role in homologous recombination for DNA repair. 